\title{
Supplementing Livelihoods of Tribal Women and Nutritional Security through Backyard Poultry in Adilabad District of Telangana, India
}

\author{
Y. Praveen Kumar*, A. Poshadri, G. Shiva Charan, M. Raghuveer, \\ A. Rama Devi and E. Rambabu
}
Krishi Vigyan Kendra, Adilabad, Professor Jayashankar Telangana State Agricultural University, India

*Corresponding author

\begin{abstract}
A B S T R A C T
Keywords

Backyard poultry, Rajashree birds,

Sustainable income,

Livelihood,

Nutrition

Article Info

Accepted:

15 June 2018

Available Online:

10 July 2018

To supplement the livelihoods of tribal women and nutritional security in Tribal villages of Adilabad district of Telangana state, Krishi Vigyan Kendra, Adilabad introduced Backyard Poultry (BYP) as a livelihood opportunity to the tribal women farmers. Under the Backyard Poultry 200 tribal women farmers were selected from the 8 adopted villages of KVK, Adilabad by Participatory Rural Appraisal (PRA) techniques. Every tribal women farmer was given 10 Rajashree birds as a unit with a worth of Rs.680 and few supplementary medicines and vaccines were also supplied. The net average income generated by tribal women farmer through Backyard Poultry per annum Rs. 7454.0. The average egg laid by one unit per annum is 932 numbers. The per capita consumption of egg in tribal villages was increased. It is also found suitable from the point of crop residues utilization at backyard of houses. Further, it also created regular subsidiary income, chicken meat and eggs for family consumption and poultry manure for improving soil fertility.
\end{abstract}

\section{Introduction}

Adilabad is one of the tribal populated districts in Telangana state. The tribal population of the district as per 2001 census is $4,16,511$ which work out to $16.74 \%$ of the total population of the district. Out of 4.16 Lakhs tribal population of the district 2.07 Lakhs inhabit the scheduled areas and covering 44 mandals of 52 mandals in the district. It has some of the unique characters viz. high rainfall (average of $1159.4 \mathrm{~mm}$ ), uneven topography, less irrigation facilities, uneven rainfall distribution, more forest area (43\%), low literacy and varied socio economic situations (Praveen Kumar et al., 2018). During kharif season, agriculture provides about 100 to 120 days employment to the tribal farmers and seasonal agriculture is not able to provide full employment to the workforce. Vulnerability of the tribes in the district comes from a high level of dependence on rain fed agriculture, which is least diversified, a cotton dominated monocropped system that does not give enough income to farmers. A small land holdings, low 
agricultural productivity and low incomes have led to rising indebtedness and also leading to migration from Gudams (tribal hamlets) to cities for their livelihood. The life of the tribals is increasingly vulnerable due to a lack of awareness on sustainable income generation activities to their resource base.

Rearing of poultry birds in the backyards, one of the age old practices in India and is a promising option for rural livelihoods and also provides valuable animal protein source through egg and chicken meat (Table 1). Poultry industry in India has transformed itself from the age-old backyard farming into a dynamic agri-based industry. India is currently producing 2.75 million tones of chicken meat and 65.48 million (2.86 million tones) of hen eggs/year (ICAR-DPR, 2012). Market driven backyard poultry enterprises are being recognized as a stepping stone for the poorest households enabling them to take the first step towards breaking out of the vicious circle of poverty and deprivation (Chaturvedani et al., 2015). Protein energy malnutrition is a common phenomenon in the diets of tribal people as their diets are predominantly based on cereals and millets which contain low quality protein. Thus, need of animal protein with high biological value can be met through eggs and chicken meat. Backyard poultry farming not only meets the nutritional security of tribes but also generates self employment to tribal women and provides supplementary income. There is also growing evidence to demonstrate the role of rural poultry farming in enhancing the food and nutrition security of the poorest households, reducing the livelihood vulnerability, insecurity and promotion of gender equity (Ahuja and Sen, 2007).

Tribals are well aware of taste of desi chicken and accept it widely and are in much demand. From commercial point of view, good egg yielding capacity, negligible feed cost, gains fine body weight and very easy to manage are few of its unique features of Rajasri poultry breed was selected for backyard poultry in the district (Naga Raja Kumari and Subrahmanyeswari, 2014). In view of the above gaps, to supplements the livelihoods and nutritional security of tribal's in the district, Krishi Vigyan Kendra, Adilabad under Rashtriya Krishi Vikas Yojana (RKVY) and Tribal Sub Plan (TSP) supplied backyard poultry (Rajasri birds) units to enhance subsidiary income of tribal women's.

\section{Materials and Methods}

Based on socioeconomic level of tribal women farmers, who are interested and having rearing knowledge on backyard poultry were chosen for Rajasri backyard poultry farming intervention in the adopted villages and other tribal hamlets. The Krishi Vigyan Kendra, Adilabad organized off and on Campus training and demonstration programmes on "Backyard Poultry Rearing" for tribal women. During 2015-16 to 2017-18 more than 5000 Rajasri birds (vaccinated against Ranikhet) have been distributed among around 482 beneficiaries of 34 villages under Rashtriya Krishi Vikas Yojana (RKVY) and Tribal Sub Plan (TSP) programmes.

Performance of backyard poultry in 34 village's (Table 2) were assed in order to understand the role of backyard poultry farming in sustaining poor people's livelihoods. This study also focused on its supplementation to livelihoods, household nutrition, and empowerment. The backyard poultry units were scattered over various villages of districts. Purposive sampling techniques were used to select sample for the study (Dhaka et al., 2017). A total 35 backyard poultry rearers were selected for the study and visited 35 units personally with a pre tested interview schedule to collect data on mortality rate, number of birds sold in market, 
body weight, number of eggs laid per annum per bird, revenue generated from eggs sold in the market, hatching of eggs, expected income and income generated by women farmer by using a well structured and pre-tested questionnaire. The collected data were statistically analyzed to draw inferences.

\section{Results and Discussion}

A unit of one male and 9 female Rajasri poultry birds (10 weeks old) was supplied to the tribal women after deworming and vaccination against Ranikhet disease. The beneficiaries were trained on selection of eggs, pre-incubation storage method of eggs, vaccination and deworming of birds. On enquiry at the beginning of the scheme, only 400 women farmers had prior exposure of rearing desi birds out of 482 women beneficiaries. Among 482 tribal women only 50 women had the experience of hatching eggs.

The results presented in table 3 and 4 revealed that through backyard Rajasri poultry farming every tribal women farmer in the tribal village of Telangaraoguda got a yield of 750 to 1190 eggs per annum with almost no or meager investment was emerged as important benefit and given highest priority for domestic consumption of eggs to combat against protein energy malnutrition among tribes. The next most important mentioned benefit was additional source of income through selling of eggs and birds per annum per beneficiary was Rs. 4440 to 8060 . In two seasons beneficiaries incubated 20 to 24 eggs under desi birds for the production of chicks. An average of chicks survived per annum was 6-10. The average expected income from the existing poultry birds in coming days is Rs. 1100 to 2200 . Per annum an average income generated through a backyard poultry unit of 10 Rajasri birds is from Rs. 5860 to 9458. Apart from this Backyard poultry farming can be efficiently convert waste material (insects, ants, fallen grains, green grass, kitchen waste, vegetable waste etc. in the backyard of house) in to egg and chicken meat for human consumption. It was further considered that it alleviates protein energy malnutrition in vulnerable groups, aids in enhancing the soil fertility and integrates well with other agricultural operations.

Table.1 Characteristic features of Rajasri backyard Poultry birds listed by Sri P.V. Narasimha Rao Telangana State University for Veterinary, Animal and Fishery Sciences,

(SPVNRTSUVAS), Rajendranagar, Hyderabad

\begin{tabular}{|r|l|l|}
\hline S.No & Characteristics & values \\
\hline $\mathbf{1}$ & Body weight at 10 week & $550-650 \mathrm{~g}$ \\
\hline $\mathbf{2}$ & Body weight at 18 week & $1.5 \mathrm{~kg}$ \\
\hline $\mathbf{3}$ & Age at sexual maturity & 165 days \\
\hline $\mathbf{4}$ & Body weight at sexual maturity & $1.5 \mathrm{~kg}$ \\
\hline $\mathbf{5}$ & Age at first egg (in days) & 165 \\
\hline $\mathbf{6}$ & Hen day egg production & 150 eggs a year \\
\hline $\mathbf{7}$ & Egg weight & $\sim 52 \mathrm{~g}$ \\
\hline Source: & Daida et al., $\mathbf{2 0 1 2}$. & \\
\hline
\end{tabular}


Table.2 Year wise number of Backyard poultry units distributed in the district

\begin{tabular}{|c|c|c|c|c|c|}
\hline S.No & Year & $\begin{array}{l}\text { No. of Rajasri } \\
\text { birds supplied }\end{array}$ & Villages & $\begin{array}{l}\text { Unit size } \\
\text { (No. of } \\
\text { birds) }\end{array}$ & $\begin{array}{c}\text { No. of } \\
\text { beneficiaries }\end{array}$ \\
\hline 1 & $2015-16$ & 2195 & $\begin{array}{l}\text { Gourapur, Pataguda, Ganpur, } \\
\text { Girigoan, Anthnamguda, } \\
\text { sonkhas, Ganeshpur, Kadki, } \\
\text { Varur, Jarri, Tattiguda, } \\
\text { Bheemguda, Gandigopalpur, } \\
\text { Luxettipet, Maisampet, } \\
\text { Shekguda, Sherguda and } \\
\text { Tokkiguda }\end{array}$ & 12 & 182 \\
\hline 2 & 2016-17 & 1815 & $\begin{array}{l}\text { Talamadugu, Bela, Tamsi, } \\
\text { Indravelly, Utnoor and Kadem } \\
\text { Mandals }\end{array}$ & 10 & 180 \\
\hline 3 & 2017-18 & 1200 & $\begin{array}{l}\text { Soyamguda, Laltekidi, } \\
\text { Marthiguda, Kannapur, } \\
\text { Kanpurguda, Dharmasagar, } \\
\text { Pochampally, Muthyam pet, } \\
\text { Kolamguda, Dhodanda }\end{array}$ & 10 & 120 \\
\hline
\end{tabular}

Table.3 Economics of Rajasri backyard poultry farming in a tribal village Telangaraoguda, Adilabad District

\begin{tabular}{|c|l|c|}
\hline S.No & Particulars & 35 \\
\hline 1 & Number of beneficiaries & 350 (10birds/beneficiary) \\
\hline 2 & Number of Rajasri birds distributed & $32.6 \%$ \\
\hline 3 & Mortality rate (in a year) & $3-6$ \\
\hline 3 & Average of number of birds sold in market & 1948.00 \\
\hline 4 & $\begin{array}{l}\text { Average income generated by farmer for selling birds @ cost } \\
\text { of 550 per birds (weight of bird: 4-5 kg) }\end{array}$ & $150-165$ \\
\hline 5 & Number of eggs laid per annum per bird & 3730 \\
\hline 6 & $\begin{array}{l}\text { Average revenue generated from eggs sold in the market per } \\
\text { annum @ Rs.4/egg }\end{array}$ & $7-8$ \\
\hline 7 & Average number of chicks produced from eggs per farmer & $25 \%$ \\
\hline 8 & Mortality rate in chicks (\%) & 1775.0 \\
\hline 9 & $\begin{array}{l}\text { The average expected income from the existing birds (2-4 } \\
\text { birds) }\end{array}$ & 7454.00 \\
\hline 10 & Total average income per farmer/annum & 23800 \\
\hline 11 & $\begin{array}{l}\text { Total initial investment by KVK for this intervention(per } \\
\text { birds @ Rs. 68) }\end{array}$ & 260922 \\
\hline 12 & Total average revenue output produced by 35 farmers/annum & $11: 1$ \\
\hline & B:C ratio & \\
\hline
\end{tabular}


Table.4 Beneficiary wise Rajasri backyard poultry performance

\begin{tabular}{|c|c|c|c|c|c|c|c|c|c|c|c|c|}
\hline $\begin{array}{l}\stackrel{0}{Z} \\
\dot{\infty}\end{array}$ & $\begin{array}{l}\frac{n}{0} \\
: 0 \\
\ddot{0} \\
\dot{0} \\
\dot{0}\end{array}$ & 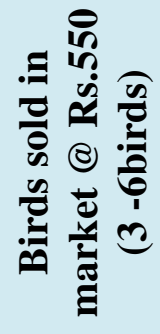 & 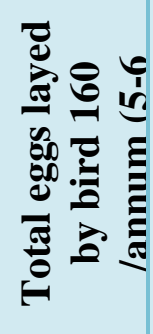 & 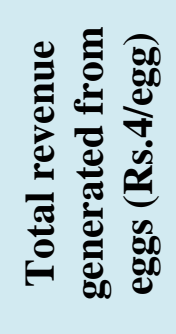 & 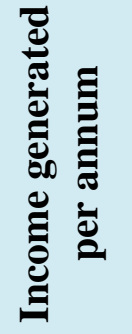 & 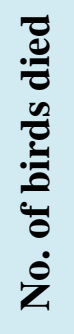 & 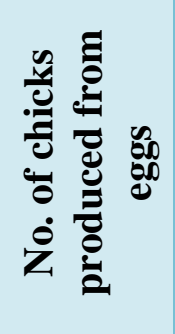 & 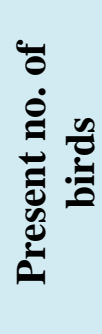 & 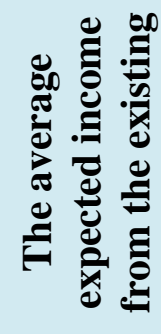 & 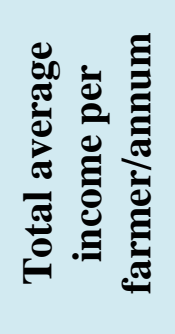 & ब & 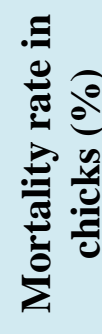 \\
\hline 1 & 10 & 1650 & 775 & 3100 & 4750 & 3 & 7 & 4 & 2200 & 6950 & 30 & 23 \\
\hline 2 & 10 & 1650 & 990 & 3960 & 5610 & 4 & 8 & 3 & 1650 & 7260 & 40 & 27 \\
\hline 3 & 10 & 1650 & 850 & 3400 & 5050 & 3 & 10 & 3 & 1650 & 6700 & 30 & 33 \\
\hline 4 & 10 & 1100 & 1020 & 4080 & 5180 & 5 & 8 & 3 & 1650 & 6830 & 50 & 27 \\
\hline 5 & 10 & 2750 & 805 & 3220 & 5970 & 2 & 9 & 3 & 1650 & 7620 & 20 & 30 \\
\hline 6 & 10 & 2200 & 750 & 3000 & 5200 & 3 & 7 & 3 & 1650 & 6850 & 30 & 23 \\
\hline 7 & 10 & 1650 & 790 & 3160 & 4810 & 3 & 8 & 4 & 2200 & 7010 & 30 & 27 \\
\hline 8 & 10 & 2200 & 894 & 3576 & 5776 & 3 & 6 & 3 & 1650 & 7426 & 30 & 20 \\
\hline 9 & 10 & 1650 & 960 & 3840 & 5490 & 4 & 8 & 3 & 1650 & 7140 & 40 & 27 \\
\hline 10 & 10 & 1100 & 1050 & 4200 & 5300 & 5 & 8 & 3 & 1650 & 6950 & 50 & 27 \\
\hline 11 & 10 & 1650 & 850 & 3400 & 5050 & 3 & 7 & 4 & 2200 & 7250 & 30 & 23 \\
\hline 12 & 10 & 1100 & 960 & 3840 & 4940 & 5 & 8 & 3 & 1650 & 6590 & 50 & 27 \\
\hline 13 & 10 & 2750 & 680 & 2720 & 5470 & 1 & 8 & 4 & 2200 & 7670 & 10 & 27 \\
\hline 14 & 10 & 550 & 1020 & 4080 & 4630 & 6 & 5 & 3 & 1650 & 6280 & 60 & 17 \\
\hline 15 & 10 & 3300 & 1190 & 4760 & 8060 & 2 & 8 & 2 & 1100 & 9160 & 20 & 27 \\
\hline 16 & 10 & 1650 & 960 & 3840 & 5490 & 3 & 8 & 4 & 2200 & 7690 & 30 & 27 \\
\hline 17 & 10 & 2200 & 1020 & 4080 & 6280 & 2 & 8 & 4 & 2200 & 8480 & 20 & 27 \\
\hline 18 & 10 & 1650 & 990 & 3960 & 5610 & 5 & 6 & 2 & 1100 & 6710 & 50 & 20 \\
\hline 19 & 10 & 2200 & 1120 & 4480 & 6680 & 2 & 8 & 4 & 2200 & 8880 & 20 & 27 \\
\hline 20 & 10 & 3300 & 1127 & 4508 & 7808 & 1 & 8 & 3 & 1650 & 9458 & 10 & 27 \\
\hline
\end{tabular}


Int.J.Curr.Microbiol.App.Sci (2018) 7(7): 1858-1864

\begin{tabular}{|c|c|c|c|c|c|c|c|c|c|c|c|c|}
\hline 21 & 10 & 2200 & 990 & 3960 & 6160 & 2 & 7 & 4 & 2200 & 8360 & 20 & 23 \\
\hline 22 & 10 & 1650 & 790 & 3160 & 4810 & 3 & 8 & 4 & 2200 & 7010 & 30 & 27 \\
\hline 23 & 10 & 2750 & 960 & 3840 & 6590 & 2 & 7 & 3 & 1650 & 8240 & 20 & 23 \\
\hline 24 & 10 & 2750 & 1085 & 4340 & 7090 & 2 & 10 & 3 & 1650 & 8740 & 20 & 33 \\
\hline 25 & 10 & 1100 & 640 & 2560 & 3660 & 4 & 8 & 4 & 2200 & 5860 & 40 & 27 \\
\hline 26 & 10 & 2200 & 800 & 3200 & 5400 & 3 & 7 & 3 & 1650 & 7050 & 30 & 23 \\
\hline 27 & 10 & 2750 & 1020 & 4080 & 6830 & 2 & 8 & 3 & 1650 & 8480 & 20 & 27 \\
\hline 28 & 10 & 2750 & 960 & 3840 & 6590 & 2 & 8 & 3 & 1650 & 8240 & 20 & 27 \\
\hline 29 & 10 & 2200 & 900 & 3600 & 5800 & 3 & 5 & 3 & 1650 & 7450 & 30 & 17 \\
\hline 30 & 10 & 550 & 972 & 3888 & 4438 & 6 & 8 & 3 & 1650 & 6088 & 60 & 27 \\
\hline 31 & 10 & 1650 & 942 & 3768 & 5418 & 4 & 7 & 3 & 1650 & 7068 & 40 & 23 \\
\hline 32 & 10 & 2200 & 972 & 3888 & 6088 & 2 & 6 & 4 & 2200 & 8288 & 20 & 20 \\
\hline 33 & 10 & 1100 & 1176 & 4704 & 5804 & 5 & 8 & 5 & 2750 & 8554 & 50 & 27 \\
\hline 34 & 10 & 2750 & 800 & 3200 & 5950 & 4 & 7 & 1 & 550 & 6500 & 40 & 23 \\
\hline 35 & 10 & 1650 & 835 & 3340 & 4990 & 5 & 8 & 2 & 1100 & 6090 & 50 & 27 \\
\hline Average & 350 & 1948.5 & 932.66 & 3730.63 & 5679.20 & 3.26 & 7.57 & & 1775.71 & 7454.91 & 32.57 & 25.24 \\
\hline
\end{tabular}


The results of economics of backyard poultry in a tribal village Telangaraoguda, Adilabad District presented in table 2, showed that, the mortality rate in birds and after hatching chicks mortality rate was $32.6 \%$ and $25 \%$ respectively. The average income generated by the women farmer in the village was Rs.7454 with the initial investment of Rs. 680 by KVK, Adilabad. The average revenue output by 35 beneficiaries in the village was Rs.2, 60,922/-.

In conclusion, backyard poultry farming is one of the best unique livelihood opportunities for the tribal women farmers in the district. It can generate subsidiary income by utilizing backyard wastes and provides year round protein rich food at relatively low cost to the family. The calculated cost benefit ratio of this study was 1:11 and it can be a sustainable livelihood entity for tribal families. Further, an integrated farming system inclusive of backyard poultry offer unique opportunities for maintaining and extending biodiversity to make the farm income double by 2022 .

\section{References}

Ahuja V and Sen A (2007).Viability and future of small scale commercial poultry production in developing countries. Paper presented at International Conference on Poultry in the $21^{\text {st }}$ Century: Avian Influenza and Beyond, Bangkok, November 5-7, 2007.

Chaturvedani A.K., Niranjan Lal, Khalid, N K
Khyalia and Jitendra Pratap (2015). Empowering Tribal Women through Backyard Poultry in Bastar District of Chhattisgarh. Journal of Krishi Vigyan. 3 (Special Issue), 19-22.

Daida K, S.V. Ramarao, V. Chinnipreetam, V. Ravinder reddy, B. Prakash and S. Qudratullah (2012). Improving livelihood security of rural women through Rajasree backyard poultry farming. Indian Journal of Poultry Science. 47(2), 231-233.

Dhaka B.L., G.S. Meena, R.K. Bairwa and N.L. Meena (2017). Supplementing Rural Livelihoods through Backyard Poultry Farming. International Journal of Current Microbiology and Applied Sciences. 6(4):1412-1415.

ICAR- Directorate of Poultry Research (2012). Vision 2050. http://www.pdonpoultry.org/pdpnew/i mages/extfiles/reports/vision_2050.pd f

Naga Raja Kumari K and Subrahmanyeswari B. (2014). Productive Performance of Rajasri Bird at Farmer's Backyard: A Study in Southern State of India. International Journal of Livestock Research. 4(6), 20-28.

Praveen Kumar Y, A. Poshadri, Ravi Palthiya, G. Shiva Charan and K. Pavan (2018). Livelihood Security of Tribal Farmers in Adilabad District through Goat Farming. Asian Journal of Agricultural Extension, Economics and Sociology. 23(4), 1-5.

\section{How to cite this article:}

Praveen Kumar, Y., A. Poshadri, G. Shiva Charan, M. Raghuveer, A. Rama Devi and Rambabu, E. 2018. Supplementing Livelihoods of Tribal Women and Nutritional Security through Backyard Poultry in Adilabad District of Telangana, India. Int.J.Curr.Microbiol.App.Sci. 7(07): 1858-1864. doi: https://doi.org/10.20546/ijcmas.2018.707.221 